\title{
Psychology of Turkish University Students as Electorate: The Mediating Role of Political Trust
}

\author{
Ozlem Dirilen Gumus \\ Louisiana State University-Shreveport \\ Talha Yalcinkaya \\ Hacettepe University, Ankara, Turkey \\ Alper Kayaalp ${ }^{1}$ \\ South Dakota State University
}

\begin{abstract}
Turkey has been ruled by a secular and democratic government since 1923 under the name of 'the Republic of Turkey'. In this rarely examined culture, we tested the effects of political trust $(P T)$, social values $(S V)$, system justification $(S J)$ and social dominance orientation $(S D O)$ on university students' intention of voting before the June 2015 election. Depending on the theory of planned behavior and the cognitive hierarchy model of human behavior, it is conceptualized that SV, SJ and SDO are placed higher in cognitive structure than PT, therefore PT would mediate the relations between those cognitions and the intention of voting. 284 university students completed the following questionnaires: PVQ-R, Political Trust, Social Dominance Orientation, and System Justification Scales, in addition to intention of voting, and demographics. Results show that conservation and social dominance orientation was positively related to the intention of voting for MHP and openness to change and system justification was positively related to intention of voting for AKP. When we tested the role of mediation for PT; we have found extensive evidence that, the relationships between SV (i.e. openness to change), SJ, and SDO and intention of voting for AKP and MHP were significantly mediated by PT. Ideological differences between and within left and right wing parties in Turkey were discussed to explain the results.

Keywords: political trust, social values, system justification, social dominance orientation
\end{abstract}

\section{Introduction}

Political orientation is related to various psychological and biological factors (Jost, Nosek, \& Gosling, 2008; Kandler, Bleidom, \& Riemann, 2012). For instance, women engage in politics less than men, but research done with children found the reverse (Alozie, Simon \& Merrill, 2003; Verba, Burns \& Schlozman, 1997). Conservative people have different moral motives than the liberal ones (Janoff-Bulman, Sheikh, \& Baldacci, 2008). Relatedly, right and left-wing supporters differ in their moral reasoning (Emler, Renwick, \& Malone, 1983). Although results are mixed, research shows that while the left voters score high on some personality domains, the right voters' scores are high on the others (Caprara et al, 2017; Caprara, Barbaranelli, \& Zimbardo, 2002; Caprara, Schwartz, Capanna, Vecchione, \& Barbaranelli, 2006; Rooduijin et al, 2017; Vecchione, Schoen, Castro, Cieciuch, Pavlopoulos, \& Caprara, 2011). Political orientation is one of the key variables that determines which party people will intend to vote.

Voting is one way of community involvement and political socialization (Hennessy, Carpini, Blank, Winneg, \& Jamieson, 2015; Lee, Oh, Lee, \& Kim, 2018) and is affected by various factors. Researchers explain that classical voting behavior is a result of group affiliation such as religion and ethnicity. Contemporary researchers use different models for understanding voting behavior such as combination of demographics, preexisting political positions, issue priorities, candidate's personality and party performance (Hennessy et al, 2015).

This study is designed to examine the psycho-social predictors of voting intention. It can be considered to be a test of the theory of planned behavior and the cognitive hierarchy model of human behavior, which argues that social values, system justification and social dominance orientation are placed higher in cognitive structure than attitudes (e.g. political trust), intentions and behaviors. Therefore, the mediation effect of political trust between those cognitions and the intention of voting was tested in this study. On the other hand, this study is an attempt to understand the differences among Turkish conservatives, who intend to vote for either Ak Parti (AKP) (Islamist Party) or Milliyetci Hareket Partisi (MHP) (Nationalist party) Since there are two conservative

\footnotetext{
${ }^{1}$ Corresponding author: alper.kayaalp@sdstate.edu
} 
parties in Turkey, what might be the reason why some conservatives are attracted to MHP, and some others to AKP.

Before we introduce each of these variables, we will next focus on the mediating role of political trust on the relationship between psycho-social predictors and voting intention. The mediation model is based on the following theories.

Theory of Planned Behavior. As a result of their studies on the relationship between attitudes and behaviors, Fishbein and Ajzen (1975) developed the theory of reasoned action which has been used to predict behavioral intentions and behaviors. Basically, the theory asserts that attitudes predict behaviors through behavioral intentions. The model eventually evolved into the theory of planned behavior, including other variables such as perceived behavioral control, beliefs and subjective norms (Ajzen, 1985), however attitudes, intentions and behaviors were still correlated on a continuum (see Figure 1). Ajzen's planned behavior approach became a tool for understanding, predicting and changing human social behavior (Ajzen, 2012).

According to Ajzen (1991) the theory of planned behavior put forward three concepts as determinants of intention. First, attitude means the extent of evaluation whether the behavior is in her/his favor or not. Subjective norm as the second predictor refers to impact of significant others on people's actions and behaviors. If the society favors an action, s/he will be more likely to behave in the same way. Thirdly, perceived behavioral control is the perception of the individual regarding the availability of resources or opportunities to achieve certain behavior. If the favorability of attitude, support of significant others (subjective norms) and perceived control are high, the intention to perform behavior will be stronger. The relative importance of these three determinants in anticipation of intention vary according to behaviors and situations.

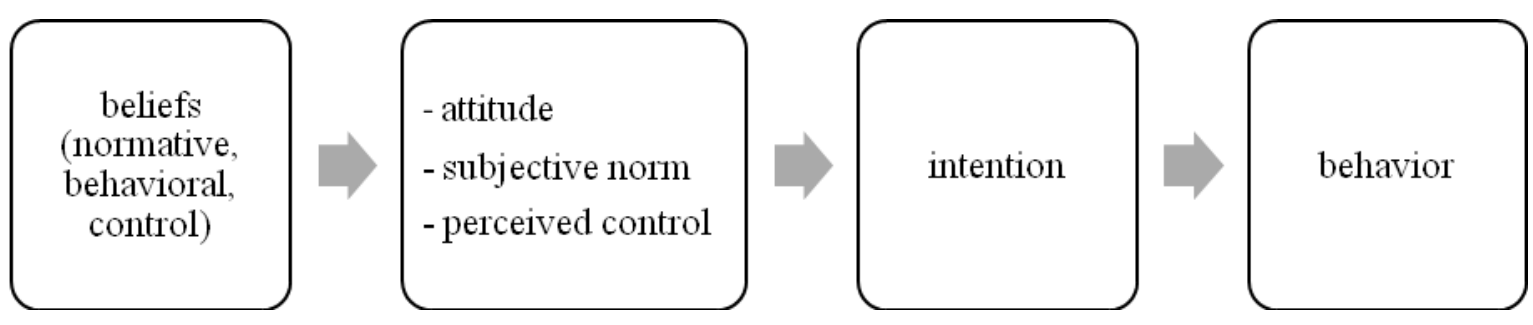

Figure 1. A basic model for the theory of planned behavior

Cognitive hierarchy model of human behavior. In relation to Ajzen and Fishbein's model, Fulton and his colleagues (1996) developed another model starting with values and followed by basic beliefs, general attitudes and beliefs, higher order attitudes and norms, behavioral intentions and behaviors. Values affect behaviors through other variables placed in between. Values provide a baseline for attitudes and beliefs, which in turn influence behavior and intention (Fulton, Manfredo, \& Lipscomb, 1996; Vaske \& Donnelly, 1999). This hierarchy is shown with an inverted pyramid in which the elements build upon one another (Vaske \& Donnelly, 1999) and since it is a hierarchical model, there is a gradual change in some criteria from top to the bottom. These are the count, stability in time and across different situations and centrality in cognitive structure. For example, behaviors change faster in time, are specific to situations and less central to the cognitive structure, but values are few (i.e. Schwartz identified 10 social values in 1992), they are stable and transcend on multiple situations (i.e. one tends to be honest in many circumstances if s/he values honesty) (Vaske \& Donnelly, 1999) (see Figure 2). 

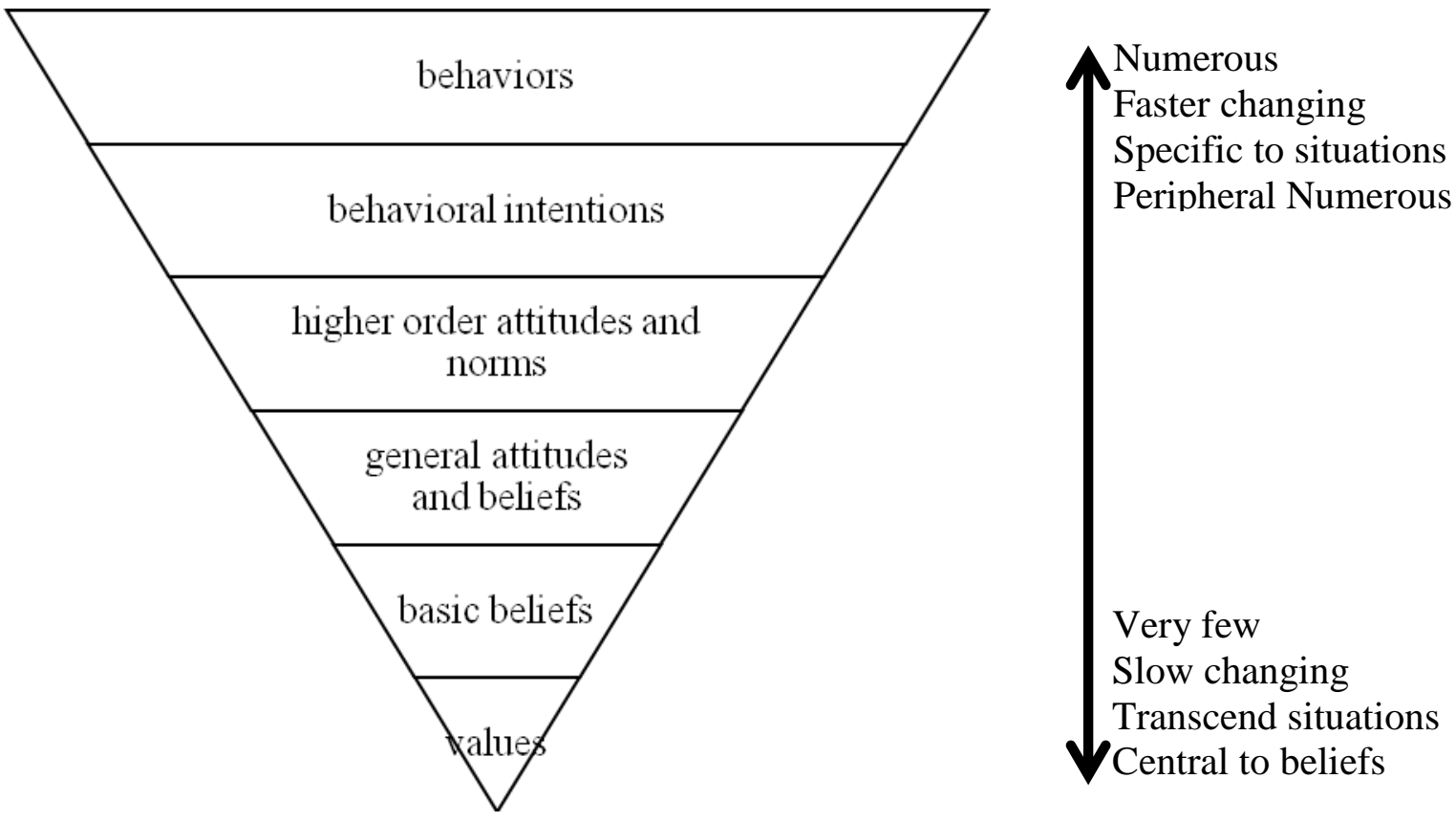

Figure 2. Cognitive hierarchy model of human behavior

In our study, these two models will assist to understand individual-level intention of voting for certain parties. Mainly, the predictors of intention of voting will be tested. We argue that political trust, as a positive attitude towards the political system, will affect intention of voting and it is affected by basic beliefs such as social dominance orientation, system justification, and social values.

Therefore, we predicted that:

H1a: Political trust will mediate the relationship between values and voting intention.

H1b: Political trust will mediate the relationship between social dominance orientation and voting intention.

H1c: Political trust will mediate the relationship between system justification and voting intention.

In the following section, these variables will be introduced.

\section{Psycho-social Predictors of Intention of Voting}

Political Trust. Political trust consists of three domains: fiduciary expectation, honesty, and competence. First, fiduciary expectation is the level satisfaction that all members of the country have and their moral expectations from the members of parliament. Second, honesty refers to public evaluations on whether the members of parliament are trustworthy, for example whether they are loyal to their words. Third, competence refers to the perception of citizens about members of parliament in terms of their intellectual capacity, decisionmaking and diplomatic skills (Çoymak, 2009).

Political trust is a positive perception of or a positive attitude towards the political system and governmental institutions in society. It is composed of social trust, general satisfaction and economic confidence (Kong, 2014). Political institutions working in favor of the public and consistent with their opinions increase the level of political trust in that society (Ersoy \& Uysal, 2018; Grimmelikhuijsen and Knies, 2017; Citrin, 1974; Hetherington, 1998). Newton (2008) made a distinction between political and interpersonal trust in which political trust depends on rules, procedures and systems. Political trust is important because it establishes a connection between citizens and institutions, and promotes the nature of democracy in a way that democracies function better if people trust their government (Bianco, 1994; Chanley, Rudolph, \& Rahn, 2000; Hetherington, 2005; Mishler \& Rose, 2001). It has been observed that the levels of political trust have been decreasing around the world (Doğan, 2005; Hetherington, 1998; Putnam, 1995, 2000).

In a survey administered in Turkey (Erder, 2002), political trust was measured in two ways, based on problem solving ability and the ability to preserve the country from danger. Results revealed parallel scores for 
both criteria for all four political parties. The AKP scored the highest with 65\%, followed by HDP with 55\%. CHP and MHP both received 45\%, but it was the MHP who recorded a sharp decrease in trust rates from 75\% to $45 \%$ since the 1999 elections. Both Kumbaracibaşı (2014) and Çarkoğlu (2007) showed that left-wing, specifically the CHP voters, reported that they were not satisfied with the economic policies and they do not trust the political institutions in general. In addition, credibility and competence evaluations affect party performances at political elections, and this might help the AKP raise their votes (Çarkoğlu \& Hinnich, 2006). Kalayoğlu (2017) stated that young people abstain from voting because they do not trust the Turkish political system, and recently, some younger voters punished the AKP via blank voting, due to the deterioration of their economic well-being.

In other words, contrary to the AKP but similar to the MHP voters, the CHP voters do not think either their representatives or the representatives of the AKP are competent and trustworthy. In addition, low levels of political trust are a source of blank voting.

Therefore, we predicted that:

H2a: Political trust will positively predict intention of voting for AKP.

H2b: Political trust will negatively predict intention of voting for CHP, MHP and blank-voting.

Social Values. Values are defined as the concepts and beliefs that guide behaviors to attain desirable outcomes. Several studies by Schwartz and his colleagues succeeded in identifying 10 basic values that shape individual decision-making, behavior and attitudes (Schwartz, 1992, 2006; Schwartz \& Bilsky, 1990; Schwartz et al., 2012). These are classified under four categories: transcendence of self-interest in the service of others (universalism and benevolence), conservation of the status quo (conformity, tradition and security), openness to change (self-direction, stimulation and hedonism) and self-enhancement (achievement and power).

Research shows that social values are related to political ideology and attitudes (Barnea \& Schwartz,1998; Tarman, 2010). Center-left voters score higher in transcendence of self-interest in the service of others and autonomy of thought and action (self-direction) and lower in conservation of the status quo and personal success (achievement) compared to the center-right voters (Caprara et al., 2006; Devos, Spini, \& Schwartz, 2002; Thorisdottir, Jost, Liviatan, \& Shrout, 2007; Kotluk \& Kocakaya, 2018). Similarly, DirilenGümüş (2009) found that the right-wing is characterized by power and conservation while the left-wing is characterized by universalism. However, in a cross-cultural study where she compared Turkish and American samples, Dirilen-Gümüş (2010) found that none of the social value types predict intention of voting for the leftist party, namely CHP.

Specifically, conservatism is considered to be a powerful predictor of social and political attitudes (Wilson as cited in Pratto, Sidanius, Stallworth \& Malle, 1994). In addition, individuals who have a high level of social dominance orientation and authoritarian personality score significantly higher at political-economic conservatism (Pratto et al., 1994). Furthermore, social dominance orientation is regarded as a central indicator of social conservatism (Altemeyer, 1998; Duckitt, 2001).

According to Kalaycioğlu (2007), during the period following the Cold War, votes for traditional and conservative right-wing political parties increased and "conservatism" became a political code describing the main idea of right-wing ideology in Turkish politics. For example, "Leader, organization and doctrine", which is the widely known saying of the MHP, could not be questioned. The ex-leader (Türkeş) of MHP's leadership was never questioned therefore his dominance deepened among voters (Akgün, 2002). In addition, MHP voters are those who were highly conservative in terms of sexuality and male-female equality (Y1lmaz, 2008).

Even though AKP voters define themselves as 'religious conservatives' (Kalaycioğlu, 2017), it has been open to change in several respects. Even though, AKP defines itself as a center-right party, tries transform political Islam into 'a moderate conservative democratic party' (Özbudun, 2006). Outstanding achievement of the AKP in 2002 showed that the party could gain attraction of conservative voters from the Turkish right (Kalaycioğlu, 2007).

Therefore, we predicted that:

H2c: Conservation will positively predict intention of voting for AKP and MHP.

$\mathrm{H} 2 \mathrm{~d}$ : Openness to change will positively predict intention of voting for AKP.

Social Dominance Orientation (SDO) is defined as one's degree of desire to dominate in-group people and be superior to out-groups (Pratto et al., 1994), and the perception that the world is competitive (Ho et al., 2012; Karakus, 2018). People who have high levels of SDO have more tendency to consider hierarchies as inevitable (Duckitt, 2001). Similarly, Overbeck, Jost, Mosso and Flizik (2004) advocated that members of low status groups who have low social dominance orientation resist the status quo more, whereas those with high levels of SDO try to justify the system. Sidanius, Kteily, Sheehy-Skeffington, Ho, Sibley and Duriez (2013) claim that SDO anticipates affirmation of ideologies which legitimize social inequality, political orientation and occupational choice. Studies reveal that levels of SDO change according to gender; basically that men show 
higher levels of SDO (Sidanius, Levin, Liu, \& Pratto, 2000; Sidanius \& Pratto, 1999), and right-wing people support a powerful leader, military government and authoritarianism (Çarkoğlu, 2007; Kayaalp, 2018).

A sign of social dominance orientation in Turkish people shows they generally do not favor women leaders, the protection of ethnic/religious minorities, and aid to the poor (Pratto et al., 2013). According to Dixon and Ergin (2010), social dominance orientation and authoritarianism can explain negative beliefs about minorities, specifically anti-Kurdish beliefs, as a sign of conservatism and nationalism.

Therefore, we predicted that:

H2e: Social dominance orientation will positively predict intention of voting for MHP.

\section{System Justification}

System justification was first introduced in literature by Jost and Banaji (1994) as people's approval and legitimization of social, political and economic systems, even if attitudes conflict with personal and group interests. This theory was later revised by Jost, Banaji and Nosek (2004). System justification is similar but not the same as ego and group justification (Jost \& Banaji, 1994).

People benefit from system justification because it can function as a guard against illegitimate and uncertain system conditions, and the fear of political unrest. It provides people a sense of stability and security therefore decreases their anxiety and feelings of discrepancy, which is known as palliative function (Owuamalam, Rubin, \& Spears, 2018; Jost et al., 2004; Jost \& Hunyady, 2002; Kay, Gaucher, Napier, Callan, \& Laurin, 2008; Karatas \& Oral, 2015). Even though their motives differ, both advantaged and disadvantaged groups tend to justify the system (Jost, Burgess \& Mosso, 2001; Jost, Glaser, Kruglanski, \& Sulloway, 2003). Dirilen-Gümüş (2011) proposed that political ideology influences system justifying thoughts. Particularly, rightwing supporters justify the system more than left-wing people do. Additionally, people who are high on social dominance orientation are also high on system justification, and people who justify the system trust the political institutions more than their counterparts (Sonmez, 2014). Therefore, we predicted that:

H2f: System justification will positively predict intention of voting for AKP.

Next, the political life in Turkey will be introduced.

\section{A Rarely Examined Culture: Turkey}

Turkey is placed between the continents of Europe, Asia and Africa. The Republic of Turkey is a secular and democratic government founded in 1923. Before 1923, the Ottoman Empire ruled as a monarchical government. The Empire controlled a large area from the Balkans to northern Africa, and included a diverse population with very different ethnic and religious backgrounds. Inhabitants were mainly Arabic, Kurdish and Turkish Muslims followed by Christian and Jewish Europeans (Zurcher, 2004).

The Turkish Republic was established in 1923 under the leadership of Mustafa Kemal Atatürk. A secular and democratic government was founded with new revolutions in political, economic, cultural, legal and social areas (Dirilen-Gümüş \& Büyükşahin-Sunal, 2012). By 1925, Turkey had been governed by a single party regime for twenty years and was ruled by the Republican People's Party (CHP) before it was converted into a multi-party system in 1945. Since then, there has been at least two political parties represented at the Grand National Assembly of Turkey (Karpat, 1962; TÜİK, 2012).

Between 1950-2002, people voted for the right-wing parties more than the left-wing parties, with a voting percentage ranging between 55-68\%. Not only military interventions, but also natural disasters and economic factors affected politics in Turkey. For example, several parties were closed because of military interventions in 1960 and 1980, and a devastating earthquake in 1999 affected general election results that year. The Democrat Party (DP) which ruled the government for 10 years starting in the 1950s, earned and lost votes depending on its economic policies during this period.

In the 1990s, pro-Islamic and ultra-nationalist parties appeared on the electoral scene for the first time. A pro-Islamic party, the Islamist Welfare Party (Refah Partisi, RP) was able to rule Turkey in a coalition with another party (DYP) in 1995 (Çarkoğlu \& Hinich, 2006; İnan, 2007; Özbudun, 2006). The Justice and Development Party (AKP) originated from one of the pro-Islamic parties and introduced itself as being closer to the center-right mindset. The AKP participated in the 2002 elections for the first time, and have represented the majority in the Grand National Assembly of Turkey since then (Özbudun, 2006). After the Virtue Party was dissolved in 2001, some of its members founded the AKP. Starting with 34\% votes in the 2002 general elections, at least $40 \%$ of the votes were claimed by the AKP in the following five general elections, which made the AKP the winner in each election. According to Ercins (2007), the AKP increased its votes because of its call for Islamic brotherhood, the need for economic security created by previous ruling parties, and leader Recep T. Erdoğan's previous political successes and his moderate speeches during elections. The AKP has been supported by both nationalist and religious groups. 
In his book, Erder presented socio-demographic characteristics of party advocates of four political parties in Turkey from the 2002 elections: AKP, CHP, HDP (People's Democratic Party) and MHP (the Nationalist Action Party). In terms of education level, the CHP voters were the most educated and the AKP voters were the least. Males mainly preferred to vote for the CHP, the MHP or the AKP while majority of the HDP voters were females. The urban/rural vote ratio was close to one to one for the AKP and the HDP, but urban voters selected the CHP more than rural voters, and it was the reverse for the MHP (Erder, 2002). Lastly, blank voters were defined as highly educated people who generally live in urban areas and metropolises (Kalaycioğlu, 2017). More recent studies show that AKP voters are mainly young and female, indicating a change in the AKP profile (Başlevent, Kirmanoğlu, \& Şenatalar, 2009; Çarkoğlu 2008).

Political Ideologies in Turkey. According to Özbudun (2006), "In the Turkish context, the 'right' refers to a commitment to religious, conservative and nationalist values, while the 'left' is defined primarily in terms of secularism" (p. 135). Research shows that left-wing voters in Turkey are tolerant, low in religiosity, open to change and democratically oriented whereas right-wing voters are low in tolerance and trust and discontented (Çarkoglu, 2007). The same study shows that Turkish people place themselves into one of the three main political orientations instead of two: right, left and center. Political ideologies may evolve in time, but it is very difficult to move from right to left or vice versa. Instead, some factors such as the change in the level of religiosity may move people from the center to the right/left or from the right/left to the center (Çarkoglu, 2007).

According to Ercins (2007), socio-economic factors influence voter's behavior in general, and there are similar relationships in Turkey. Economic factors, i.e. economic crises and GDP, are critical, but political identity (right/left orientation) has the strongest effect. However, instances of military coups resulting in political parties being dissolved resulted in degeneration of Turkish party identities. Over time, political orientations were defined by the level of religiosity and socio-economic status (SES), which affected voting behavior to some degree. Political parties representing Islam, Kurdish nationalism and radical Turkish nationalism gained support more and more since 1987 (Ercins, 2007).

In summary, several sociological (SES, education, religion, etc.), societal (economic crises, military effects, etc.) and psychological factors have affected the voting behavior of Turkish citizens. In this study, we are interested in the effect of certain psycho-social factors that have been studied by political and social psychologists for years, namely social values, social dominance orientation, system justification, and political trust.

\section{Method \\ Data and Sample}

The data were obtained from a survey conducted in Turkey over 15 days in May in 2015. The survey was designed to examine the mediation role that political trust plays in relationship between social values, system justification and social dominance orientation and the intention of voting for conservative parties in Turkey, either AKP or MHP.

Convenience sampling, a non-probability method, was used to select the respondents. The respondents were undergraduate and graduate students attending several major universities in Ankara, Turkey. The survey was conducted by fifty undergraduate students. The surveyors were trained about the content of the survey and the way how it is administered. Surveyors received extra course credit for both participating in the survey and applying the survey to five additional participants. Informed consent of the respondents was taken and confidentiality of responses was assured. The survey did not include any question that might identify any respondent. In addition, contact information was provided for possible further questions. The majority of the respondents were contacted either in cafeterias or in libraries in the universities. It took on average 20 minutes to administer the survey. A total of 284 respondents participated in the survey. The response rate was $65 \%$.

\section{Variables and Measures}

The independent variables were "social values", "social dominance orientation", and "system justification". "Social values" were measured by Portrait Values Questionnaire-Revised including 57-item, which was designed to measure 19 values in the refined theory of social values (Schwartz et al., 2012). The scale was adapted into Turkish by Demirutku and Dirilen-Gümüş in collaboration with Schwartz (Schwartz et al., 2012). Respondents rated how similar or dissimilar these people are compared to themselves on a six-point scale ranging from 1 (very dissimilar) to 6 (very similar). Each value was represented by three items. For the purpose of this study, instead of analyzing all 19 value types, the four main value dimensions were considered. The four main values sub-scales included "openness to change" (e.g. Doing everything independently is important to him.), "self-enhancement" (e.g. Being very successful is important to him.), "self-transcendence" (e.g. He works to promote harmony and peace among diverse groups.), and "conservation" (e.g. It is important 
to him to maintain traditional values or beliefs.). The Cronbach Alpha levels are .77, .75, .86 and .84 respectively. All these values met the minimum standard level of .70.

"Social dominance orientation" (SDO) was measured by using the Turkish version of the 16-item SDO scale developed by Pratto and her colleagues (1994) and adapted to Turkish by Akbaş (2010, unpublished master thesis). Half of the items (item 9 to item 16) were reverse items (e.g., "No one group should dominate in society"). The respondents were asked to rate their agreements with the items in the continuum of "completely disagree and agree completely" on a seven-point Likert scale. Higher scores indicate higher levels of social dominance orientation. The internal reliability of the scale was found to be satisfactory $(\alpha=.86)$.

"System justification" was measured by using the scale developed by Kay and Jost (2003) and adapted to Turkish by Y1ldırım (2010). It has eight items where a seven-point scale was used (1-strongly disagree; 7strongly agree). It measures to what extent people justify the current system. Higher scores indicated higher levels of system justification. A sample item is as follows: "My country is the best country in the world to live in". The Cronbach Alpha that Kay and Jost (2003) reported was .88, and Yildirım reported .67. The internal reliability that was found in this study was .78, which is quite higher than Y1ldirım's study (2010).

The mediator variable was "political trust", which was measured by using the scale developed by Çoymak (2009), which includes 19 items (2009). Respondents answered each item on a seven-point scale ranging from 1 (strongly disagree) to 7 (strongly agree). It has three subscales including "sense of honesty" (e.g. They never tell the whole truth about their intentions), "competence" and "satisfaction of fiduciary and moral expectations" (e.g. They do everything for us to have a better life.). Eight items (1, 2, 3, 4, 7, 13, 15 and 17) were re-coded. The alpha coefficients were .88 for sense of honesty, .70 for competence (item 15 was eliminated from the analysis because it lowers the correlation), and .92 for satisfaction of fiduciary and moral expectations. Except for competence, these coefficients are the same as the coefficients reported by Çoymak (2009).

Control variable was gender, which was measured as male and female. The dependent variable was "voting intention", which was measured by the following open-ended question: "What political party would you vote for if the election was held this Sunday?". The responses were coded as " 1 " if a political party was stated and " 0 " for other responses.

\section{Results \\ Descriptive Statistics}

The majority of the participants were female (73.2\%). The average age of the participants was 20.31 $(S D=2.30)$ for females and $21.08(S D=2.93)$ for males.

The mean scores of males and females on the major variables were compared via $t$ test (Table 1). Significant gender differences were identified on openness to change $\left(M_{\text {males }}=4.86, M_{\text {females }}=5.06\right)$, selfenhancement $\left(M_{\text {males }}=4.04, M_{\text {females }}=4.26\right)$, conservation $\left(M_{\text {males }}=4.40, M_{\text {females }}=4.71\right)$ and self-transcendence $\left(M_{\text {males }}=4.93, M_{\text {females }}=5.24\right)$. Considering the gender differences on value dimensions and the disproportionate gender distribution in the sample, partial correlation analyses were carried out controlling for the effect of gender. As summarized in Table 2, participants overall reported relatively low scores of political trust dimensions, namely, sense of honesty and satisfaction of fiduciary and moral expectations. The scores on competence were higher than the other two dimensions. Social dominance and system justification scores were also below the midpoint. Among value dimensions, self-enhancement and conservation scores were relatively lower than openness to change and self-transcendence.

In addition to a short survey concerning their demographic characteristics, the participants completed the scales indicated below. Participants also indicated the political party they would vote for if an election was to be held the following Sunday. The responses gathered for this question is as follows: the participants willing to vote for AKP constituted 16.5\%, CHP 21.1\%, MHP 11.3\%, and HDP 2.8\%. The students who would use blank votes constituted $23.6 \%$. These people specifically indicated that they would vote blank. It is not simply fail to answer which party they would vote for. This is the result of increased apolitization of the youth in Turkey. Kalaycioğlu (2017) stated that young people abstain from voting because they do not trust the Turkish political system, and recently, some younger voters punished the AKP via blank voting. The rest of the participants indicated other minor parties like ANAP, SP, DSP, HEPAR, BBP, TKP, ANAPAR, EMEP and İşçi Partisi (Labor Party). Fifty out of 284 (17.6\%) participants did not answer this question. 
Table 1.

Descriptive Statistics and Partial-Correlations among the Study Variables

\begin{tabular}{|c|c|c|c|c|c|c|c|c|c|c|c|}
\hline & $M$ & $S D$ & Range & 1 & 2 & 3 & 4 & 5 & 6 & 7 & 8 \\
\hline 1. Sense of honesty & 2.65 & 1.40 & $1-7$ & & & & & & & & \\
\hline 2.Competence & 3.34 & 1.29 & $1-7$ & $72 *$ & & & & & & & \\
\hline $\begin{array}{l}\text { 3. Satisfaction of fiduciary } \\
\text { and moral expectations }\end{array}$ & 2.82 & 1.35 & $1-6.89$ & $72 *$ & $75^{*}$ & & & & & & \\
\hline $\begin{array}{l}\text { 4. Social dominance } \\
\text { orientation }\end{array}$ & 2.88 & 1.09 & $1-7$ & 20 & 19 & 20 & & & & & \\
\hline 5. System justification & 2.90 & 1.17 & $1-6.5$ & $58^{*}$ & $60 *$ & $67 *$ & $22 *$ & & & & \\
\hline 6. Openness to change & 5.01 & .65 & $2.33-6$ & $.23 *$ & .15 & .15 & .08 & .07 & & & \\
\hline 7. Self-enhancement & 4.21 & .78 & $2.33-6$ & .10 & .01 & .03 & 19 & .00 & $24 *$ & & \\
\hline 8. Self-transcendence & 5.16 & .58 & $2.93-6$ & .16 & .05 & .11 & $.24 *$ & .13 & $51 *$ & 16 & \\
\hline 9. Conservation & 4.63 & .70 & $1.53-6$ & 04 & 15 & 15 & 07 & 19 & 16 & $36^{*}$ & $52 *$ \\
\hline
\end{tabular}

Note. The gender of the participants was controlled in the correlations.

*: $p<.001$ (after controlling for Type 1 Error by using Bonferroni correction)

\section{MANCOVA Analyses}

Groups based on their intention of voting for different parties were compared on dependent variables by controlling the effect of gender. After the sample sizes were considered, it was decided to exclude HDP voters. They constituted a very small proportion of people that might have violated the assumptions of this parametric analysis.

A one-way multivariate analysis of variance was conducted (after controlling for gender) to find out if the intention of voting for different parties would be related to the scores of the study's variables; social values (four dimensions), political trust (three dimensions), system justification and social dominance orientation, which totals nine variables. Significant differences were found among four groups on the dependent measures: Wilks's $\Lambda=.61, F(9,482)=11.99, p<.001$. The multivariate eta-squared on Wilks's $\Lambda$ was quite strong with .15 .

Analyses of variances (ANCOVA) on each dependent variable were conducted as follow-up tests to the MANCOVA. Using the Bonferroni method, each ANCOVA was tested at 0.006 (found by dividing .05 by the number of dependent variables, which is 9). The ANCOVA on all political trust dimensions were significant; sense of honesty, $F(3,200)=30.47, p<.001, \eta^{2}=.31$; competence, $F(3,200)=26.57, p<.001, \eta^{2}=.29$; satisfaction of fiduciary and moral expectations, $F(3,153)=29.27, p<.001, \eta^{2}=.31$ (See Figure 3 ). 


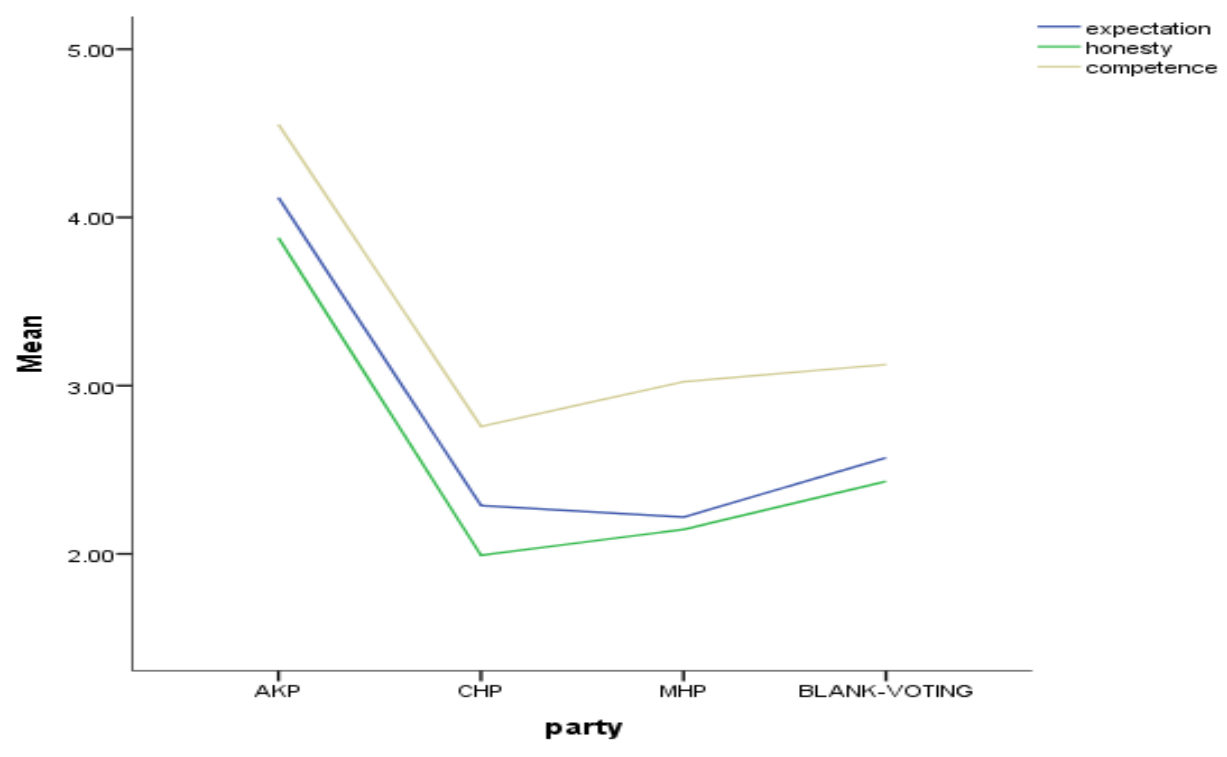

Figure 3. Means for political trust dimensions

Post hoc analyses to the Univariate ANCOVA for the political trust dimensions consisted of conducting pairwise comparisons to find which groups differ from each other. Each pairwise comparison was tested at 006 divided by 6 (number of pairwise comparisons) or the .0009 level. Significant differences were observed between the AKP and all other groups. AKP scored the highest. As a result of this analysis, we decided to consider political trust as one variable, rather than having three different dimensions.

A second one-way MANCOVA analysis was conducted to find out if the intention of voting for different parties would be related to the scores of the study's variables; social values (four dimensions), system justification and social dominance orientation, which totals six variables. Significant differences were found among four groups on the dependent measures: Wilks's $\Lambda=.61, F(18,552)=5.92, p<.001$. The multivariate etasquared on Wilks's $\Lambda$ was quite strong with .15 .

The tests on conservation, $F(3,200)=5.12, p=.002, \eta^{2}=.07$, and system justification, $F(3,200)=27.19$, $p<.001, \eta^{2}=.29$, were significant. Post hoc analyses on conservation showed that the AKP and MHP groups scored higher than Blank-vote and CHP group. Post hoc analysis on system justification showed that AKP scored higher than all other groups and there were no significant differences among other groups (See Figure 4).

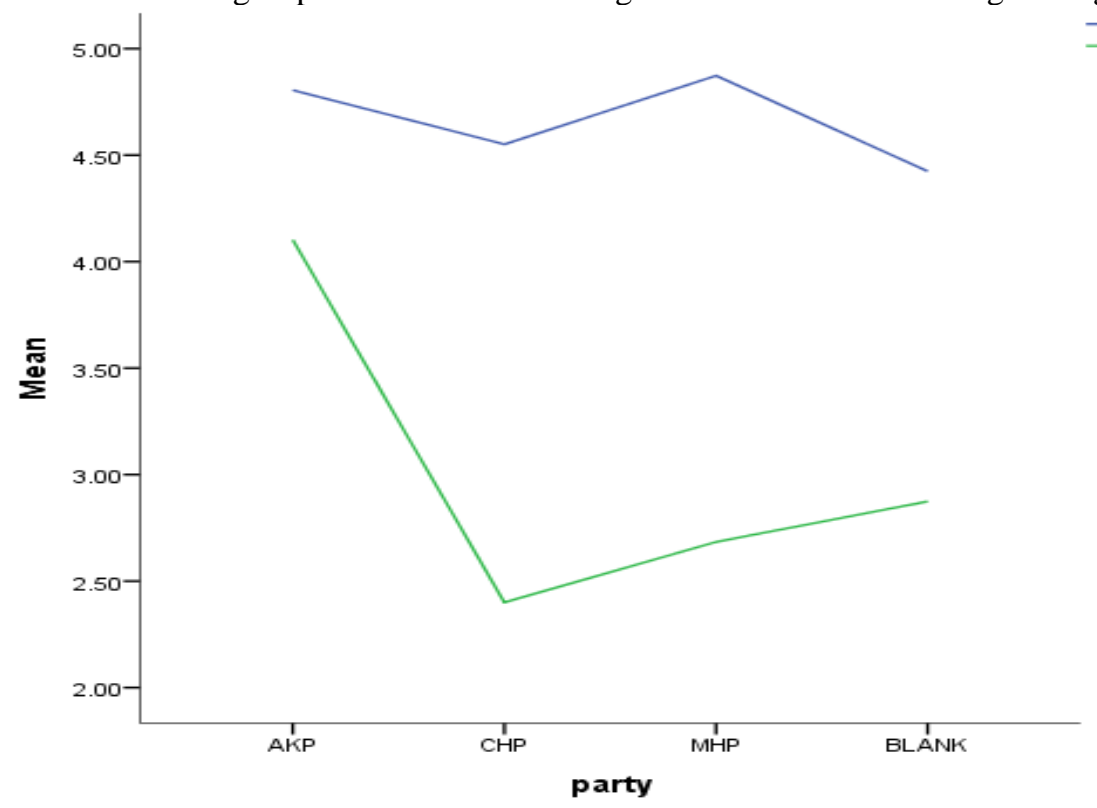

- conservation - system_justification

Figure 4. Means conservation and for system justification 


\section{Regression Analyses}

A series of hierarchical multiple regression analyses were tested after dummy-coding the intention of voting for each party: AKP, CHP, MHP, and Blank votes. Gender was entered in the first step and all other variables were entered as one set of predictors.

Predicting the intention of voting for AKP. Firstly, gender did not account for any variance in explaining the intention of voting for this party, $F(1,279)=.006, n s$. However, the addition of all other predictors increased variance to .30 , and this increase was significant, $F(8,272)=13.80, p<.001$. The predictors that positively predicted the intention of voting for AKP are: political trust $(\beta=.33, p<.001)$ (Hypothesis 2a), openness to change ( $\beta=.13, p=.04$ ) (Hypothesis $2 \mathrm{~d}$ ) and system justification $(\beta=.25, p=.001)$ (Hypothesis $2 \mathrm{f}$ ).

Predicting the intention of voting for CHP. Gender accounted for a significant level of variance in explaining the intention of voting for this party, $R^{2}=.04, F(1,279)=9.98, p=.002$. Female participants had higher levels of intention of voting for CHP $(\beta=.19, p=.002)$. The addition of all other predictors increased total variance to .11 , and this increase was significant $-R^{2}$ change $=.07, F(8,272)=4.26, p<.001$. If we look at the effects of specific predictors, none of them, except for political trust, significantly predicted intention of voting for CHP. The effect of political trust was marginal and the direction of the relationship was negative $(\beta=-.20$, $\mathrm{p}=.01$ ) (Hypothesis 2b).

Predicting the intention of voting for MHP. Gender did not account for any variance in explaining the intention of voting for this party, $F(1,279)=.02, n s$. However, the addition of all other predictors increased the variance and this increase was significant, $R^{2}$ change $=.09, F(8,272)=3.43, p<.001$. Political trust negatively predicted $(\beta=-.23, p=.005)$ and among value dimensions, conservation positively $(\beta=.26, p=.002)$ (Hypothesis 2c) predicted; in addition, social dominance orientation positively $(\beta=.17, p=.008)$ (Hypothesis $2 \mathrm{e}$ ) predicted the intention of voting for this party.

Predicting the intention of blank-voting. Gender marginally accounted for the intention of blank-voting, $R^{2}=.02, F(1,279)=4.47, p=.035$, and the addition of all other predictors increased the variance significantly, $F(8,272)=2.62, p<.01$. Political trust $(\beta=-.16, p<.05)$ (Hypothesis $2 \mathrm{~b})$, and surprisingly conservation $(\beta=-.25$, $p=.003)$, negatively predicted blank-voting.

\section{The Mediating Role of Political Trust}

Regression analysis was used to investigate the hypothesis that political trust mediates the effect of social values, system justification and social dominance orientation on voting intention.

Results indicated that openness to change, $b=-.299, \mathrm{SE}=.097, \mathrm{p}=.002$, system justification, $\mathrm{b}=.647$, $\mathrm{SE}=.048, \mathrm{p}<.001$, and social dominance orientation, $\mathrm{b}=.122, \mathrm{SE}=.052, \mathrm{p}=.020$, were significant predictors of political trust, and that political trust was a significant predictor of intention of voting for $\mathrm{AKP}, \mathrm{b}=.102, \mathrm{SE}=$ $.02, \mathrm{p}<.001$, and intention of voting for MHP, $\mathrm{b}=-.061, \mathrm{SE}=.021, \mathrm{p}<.004$. These results support the mediation hypotheses.

Openness was still a significant predictor of intention of voting for AKP after controlling for the mediator, political trust, $\mathrm{b}=.075, \mathrm{SE}=.034, \mathrm{p}=.015$, consistent with partial mediation. System justification was still a significant predictor of intention of voting for AKP after controlling for the mediator, political trust, $\mathrm{b}=.079, \mathrm{SE}=.026, \mathrm{p}<.003$, consistent with partial mediation. Social dominance orientation was still a significant predictor of intention of voting for MHP, after controlling for the mediator, $b=.05, \mathrm{SE}=.021, \mathrm{p}=.016$, consistent with partial mediation. Apart from these, conservation positively predicts intention of voting for MHP, $b=.12, \mathrm{SE}=.037, \mathrm{p}=.001$.

Approximately $29 \%$ of the variance in intention of voting for AKP was accounted for by the predictors $(\mathrm{R} 2=.289), \% 9$ of the variance in intention of voting for MHP was accounted for by the predictors (R2=.090), and $\% 47$ of the variance in political trust was accounted for by the predictors $(\mathrm{R} 2=.469)$.

The indirect effects were tested using a bootstrap estimation approach with 1000 samples (Shrout \& Bolger, 2002). The indirect effect of openness to change on intention of voting for AKP, $b=-.030, \mathrm{SE}=.014$, $95 \% \mathrm{CI}=-.065,-.010, \mathrm{p}=.002$, was significant. The indirect effect of system justification on intention of voting for AKP, $\mathrm{b}=.066, \mathrm{SE}=.018,95 \% \mathrm{CI}=.035, .108, \mathrm{p}=.002$, was significant. Lastly, the indirect coefficient of social dominance orientation on intention of voting for MHP, $\mathrm{b}=-.007, \mathrm{SE}=.004,95 \% \mathrm{CI}=-.017,-.002$, $\mathrm{p}=.011$ was significant.

The total effect of openness to change on intention of voting for AKP was not significant, $b=.045$, ns, the total effect of system justification on intention of voting for AKP was significant, $b=.145, p=.001$ and the total effect of social dominance orientation on intention of voting for MHP was significant, $b=.042, p<.05$. 
Table 2.

Direct, indirect and total effects amongst the constructs

\begin{tabular}{llllll}
\hline \multicolumn{1}{c}{ Direct Effect } & $b$ & $S E$ & $C R$ & $p$ & $\beta$ \\
\hline Openness to change $\rightarrow$ Political Trust & -.299 & .097 & -3.087 & .002 & -.16 \\
System Justification $\rightarrow$ Political trust & .647 & .048 & 13.613 & .000 & .636 \\
Social Dominance Orientation $\rightarrow$ Political Trust & .122 & .052 & 2.335 & .020 & .109 \\
Openness to change $\rightarrow$ IOV for AKP & .075 & .036 & 2.090 & .037 & .128 \\
System Justification $\rightarrow$ IOV for AKP & .079 & .022 & 3.535 & .000 & .246 \\
Social Dominance Orientation $\rightarrow$ IOV for MHP & .050 & .019 & 2.680 & .007 & .166 \\
Political trust $\rightarrow$ IOV for AKP & .102 & .022 & 4.967 & .000 & .323 \\
Political trust $\rightarrow$ IOV for MHP & -.061 & .021 & -2.911 & .004 & -.227 \\
\hline
\end{tabular}

Selected Fit Measures

\begin{tabular}{|c|c|c|c|c|c|c|c|c|c|}
\hline$C M I N$ & $D F$ & $C M I N / D F$ & $p$ & $T L I$ & CFI & $G F I$ & $R M R$ & RMSEA & PCLOSE \\
\hline 653.206 & 36 & 18.145 & .000 & .858 & .996 & .997 & .002 & .093 & .159 \\
\hline \multicolumn{10}{|c|}{ Tests for Mediation-Indirect Effects } \\
\hline \multicolumn{8}{|c|}{ Indirect Effects } & $b$ & $\beta$ \\
\hline \multicolumn{8}{|c|}{ Openness to change $\rightarrow$ IOV for AKP } & -.030 & -.052 \\
\hline \multicolumn{8}{|c|}{ System justification $\rightarrow$ IOV for AKP } & .066 & .205 \\
\hline \multicolumn{8}{|c|}{ Social Dominance Orientation $\rightarrow$ IOV for MHP } & -.007 & -.025 \\
\hline \multicolumn{8}{|c|}{ Total Effects } & $b$ & $\beta$ \\
\hline \multicolumn{8}{|c|}{ Openness to change $\rightarrow$ IOV for AKP } & .045 & .076 \\
\hline \multicolumn{8}{|c|}{ System justification $\rightarrow$ IOV for AKP } & .145 & .451 \\
\hline \multicolumn{8}{|c|}{ Social Dominance Orientation $\rightarrow$ IOV for MHP } & .042 & .141 \\
\hline
\end{tabular}

Tests for Significance of Indirect Effects

(Number of Bootstrap samples $=1000$ and Bias corrected confidence interval=95\%)

\begin{tabular}{llllll} 
Openness to change $\rightarrow$ IOV for AKP & ML Estimate & BS SE & LB 95 CI & UB 95 CI & $p$ \\
Total Effect & .045 & .032 & -.015 & .112 & .118 \\
Direct Effect & .075 & .034 & .015 & .149 & .015 \\
Indirect Effect & -.030 & .014 & -.065 & -.010 & .002 \\
& & & & & \\
System justification $\rightarrow$ IOV for AKP & ML Estimate & BS SE & LB 95 CI & UB 95 CI & $p$ \\
Total Effect & .145 & .019 & .112 & .187 & .001 \\
Direct Effect & .079 & .026 & .028 & .128 & .003 \\
Indirect Effect & .066 & .018 & .035 & .108 & .002 \\
& & & & & \\
Social Dominance Orientation $\rightarrow$ IOV for & ML Estimate & BS SE & LB 95 CI & UB 95 CI & $p$ \\
MHP & & & & & \\
Total Effect & .042 & .021 & .003 & .088 & .034 \\
Direct Effect & .050 & .021 & .009 & .096 & .016 \\
Indirect Effect & -.007 & .004 & -.017 & -.002 & .011 \\
\hline
\end{tabular}


In conclusion, political trust neutralizes the positive effect of openness to change on intention of voting for AKP, the total effect is no longer significant; political trust increases the positive effect of system justification on intention of voting for AKP, total effect is still significant; and political trust decreases the positive effect of social dominance orientation on intention of voting for MHP, the total effect is still significant.

\section{Discussion}

There are three main groups of findings in this study that are related to three social-psychological variables: social values (especially openness to change and conservation), system justification and social dominance orientation. Firstly, social values do play a significant role such that people who intend to vote for AKP and MHP have higher scores on conservation, while the opposite is the case for intention to vote for CHP and blank-voting. Regression analysis showed that conservation positively predicted intention of voting for MHP and negatively predicted blank-voting. The mediation analysis did not indicate any mediator effect of political trust for the relationship between conservation and intention for voting for either AKP or MHP.

On the other hand, another social value openness to change positively predicted intention of voting for AKP. However, the mediation analysis showed an interesting finding.

When we added political trust to the equation we gather a different pattern. It is shown that while political trust did not mediate the relationship between openness to change and the intention to vote for AKP. That is, people who priorities openness to change values such as stimulation and self-direction do intend to vote for AKP, however decreased political trust turns this relationship into insignificant. People who are open to change but have low level of political trust will not vote for AKP.

We have some other striking findings regarding system justification and social dominance orientation. People who intend to vote for AKP had higher system justification score than all other parties' supporters and it positively predicts intention of voting for this party. Our results supported previous findings, such that the rightwing participants justify the system more (AKP) than the left-wing people do (CHP). The mediation analysis showed a parallel result. The addition of political trust into the equation intention of voting for AKP has increased. That is, people who justify the political system and high level of political trust have higher intention of voting for AKP.

On the other hand, in terms of social dominance orientation, people who have higher levels of social dominance orientation have more tendencies to consider hierarchies as certain and try more to justify the system in comparison to individuals who have low levels of SDO. According to present findings, social dominance orientation positively predicted the intention of voting for MHP. As stated by Pratto and colleagues (2013), people who have low levels of SDO do not favor women leaders and in the history of MHP there has never been a woman party leader. Also, as claimed by Dixon and Ergin (2010), SDO can explain negative beliefs about minorities and MHP, as a nationalist party, has more conservative beliefs about Kurdish issues in comparison to Islamists (Akgün, 2002). In the same vein, Sidanius and colleagues (2000), found a strong relationship between SDO and racism and nationalism. The mediation analysis revealed additional contribution to the literature. When we added political trust as a mediator variable to the relationship between social dominance orientation and intention of voting for MHP, we see that political trust has a negative effect on this relationship. Such as, social dominance oriented people who have low level of political trust has lowered intention of voting for MHP, but the relationship is still positive and significant.

Lastly, the findings regarding political trust showed that there is not significant differences amongst its dimension that are sense of honesty, competence, and satisfaction of fiduciary and moral expectations. Therefore, for the rest of the analyses we considered political trust as a single variable. According to the analyses, those who intended to vote for AKP had the highest level of political trust, and it positively predicted intention of voting for AKP, inversely, negatively predicted voting for MHP, CHP and blank-voting. This variable has also partially mediated the relationship between openness to change, system justification and intention of voting for AKP, and the relationship between social dominance orientation and intention of voting for MHP.

In this study, the mediation model is intentionally developed to understand the underlying reasons of intentions of voting for AKP or MHP. Mainly religious and conservative people vote for either MHP or AKP, but what determines which party to vote for is understood that it is the political trust; people who have high levels of political trust tend to vote for AKP but who has lower political trust level tend to vote for MHP, similar to supporters of the left-wing party, CHP, and those who intends to vote blank. To explain this difference, we should focus on the different sections within conservatives in Turkey. There are two main sections: nationalists (ideology represented by MHP) and Islamists (ideology represented by AKP). From a macro level perspective, these two parties constitute the right-wing of Turkish politics.

The very essence of the divergence between these two ideologies rests on their worldviews. While the Islamism originates from the teachings of God, and therefore from unalterable truths, nationalism is based on 
an individual's philosophical beliefs that his nation is above everything, parallel to the underpinnings of social dominance orientation. Nationalists overemphasize the nation and dedicate themselves to serving and showing loyalty to their country that must be unreservedly loved. One of the main arguments of the supporters of MHP in the 1990s was "either love it, or leave it." In the MHP's ideology, "leader, organization and doctrine" should not be challenged. This is also the tradition among Islamists. Neither party's leadership was ever challenged in party conventions, and their charismatic authority has only deepened over time. Apart from some commonalities, Islamists and nationalists might differ when it comes to the Kurdish issue. Islamists think that the Kurdish people constitute a distinct ethnic entity and thus they should be given certain rights like using their language freely in public, including in educational institutions and radio and TV broadcasting (Akgün, 2002). This more positive attitude of Islamists, voters of AKP, is supported by our data, showing that these people are more open to change.

The nationalists and Islamists have always existed in the Turkish political life, either in the center or in the periphery. However, the data collected by World Values Survey researchers show that rising religiosity and intolerance in Turkey (can also be dated back to 1995) have become more evident during the AKP's rule. Findings suggest that Turkish voters are likely to continue being attracted to political parties like the AKP now and in the future, which would have important consequences for Turkey's economic, social and political relations with the West (Akgün, 2002). As it was anticipated in these years, today Turkey's relations with the Western world is more problematic and the economic indicators show that it will worsen more in time (Arin, 2013; Al-Monitor, 2017; Ahval, 2018).

\section{Discussion}

From 2002 until 2014, the AKP won three parliamentary elections with increasing vote shares each time in two local elections, two referenda, and a presidential election. The party has an obvious large amount of public support. However, throughout these years, the party has also encountered a large scale of resistance from different sections of Turkish society. The June 2015 election, prior to which we collected data, took place in a polarized context. This polarization has been especially visible since the 2013 Gezi Park protests (Kemahlıoğlu, 2015).

Although the AKP was successful in downsizing the effects of the military in Turkish politics and contributing to democracy in this dimension (Öniş, 2013), there has been a deterioration in other aspects, especially during the last few years of the party's rule. This deterioration of the AKP's rule resulted in low levels of political trust in certain sections of society that indicated citizens, on average, have a negative perception of the way the country is ruled. This discontent among citizens also affects their behaviors when they have the opportunity to speak out about their political choices. The first possibility is that discontented citizens will use the EXIT option meaning their political participation will decrease. Studies conducted in the USA indicated that there is a positive relationship between political trust and voter turnout. This is what we observed in our data. The highest percentage of people indicated that they will not vote (Blank-vote group \%23.6). There are other reasons for blank-voting behavior. Kalaycioğlu (2017) asserted that lifestyle is the most important factor; reflecting the importance of the youth's everyday practices on their conventional political participation. Besides, being female (females constitute \%73.2 of our sample), having higher levels of education (\%100 of our sample has at least high school degree) and residing in an urban area increase the probability of abstaining. Moreover, 'economic voting' exists for younger generations as they are found to be punishing the ruling Justice and Development Party (AKP) for unpromising economic prospects either individually or socially. In the 2011 general elections, the probability of abstaining increased again by $18 \%$.

A second option is that discontented voters will voice their dissatisfaction by voting for unexpected parties, mainly populist or extremist parties. Decreased levels of political trust have been considered as one of the main motivators for voting for such parties. The increase in votes for HDP, which is an extremist party, indicated how true this explanation can be. This party could not have imagined taking $13.12 \%$ of all votes in June 2015 Elections.

A third possibility is that, despite their distrust, voters will opt for loyalty by supporting a mainstream political party. This possibility can especially be anticipated in a political system where reliable exit or voice options are not available (Hooghe, Marien \& Pauwels, 2011). The results of the 2015 elections put Turkish citizens into this chaotic and stressful situation. During these times, emotions were the principle fuel of the formation of political decisions. The post-June election studies showed that socially induced anxiety was high regarding several issues, including the Democratic Opening and its possible risks, the Syrian war, ISIL, a viable risk of future economic crisis, and political ambiguity in terms of possible outcomes of a coalition government. Such anxiety was particularly high for non-AKP voters (Erişen, 2016). All in all, the fear of terrorism, economic instability and growing concerns over the inability to form a coalition government generated a fearful society. In such stressful times, people exhibit unexpected behaviors and attitudes (Kayaalp, 2016; Yigit, 2018). They 
tend to search for more political information; they are eager to learn about social issues and political participation increases; they will engage in social protests less; and they are more likely to look for a charismatic leader and be committed to his vision (Erişen, 2016). In this way, they will appear to be at peace (palliative function of system justification) since they believe that political actors will control the sources of any social and political hassles. The Turkish electorate experienced these described feelings when faced with a new election that took place on the 1 st of November 2015.

In summary, in this study, we were interested in the effect of certain psycho-social factors studied by political and social psychologists for years, namely social values, social dominance orientation, system justification, and political trust. We tested their effects on university students' intention of voting before the June 2015 election in Turkey.

Depending on the theory of planned behavior and the cognitive hierarchy model of human behavior, we hypothesized that social values, system justification and social dominance orientation are placed higher in cognitive structure than political trust, therefore political trust would mediate the relations between those cognitions and the intention of voting. Results indicate that conservation and social dominance orientation, openness to change and system justification are positively related to the intention of voting; and political trust, as a positive attitude towards the political system, affects intention of voting and affected by basic beliefs such as social dominance orientation, system justification, and social values.

\section{Limitations}

There are several limitations to be considered while interpreting the findings of the current study. First, the sample was composed of university students studying at different Turkish Universities, mainly located in the capital city of Ankara. This sample has obviously does have the capacity to reflect the general electorate population in Turkey. The heterogeneity of the sample in terms of male-female numbers may have resulted in an increase in error variances in estimations and decreased the power of the analyses. Therefore, future studies should recruit more representative and larger samples.

Second, this study tries to take a picture of the situation right before the June 2015 elections in Turkey. There are many unique characteristics of this period in Turkish political life. To see the effect of social values, system justification and social dominance orientation that are more continuous structures, longitudinal studies are needed conducted with representative samples. Cross-cultural comparisons may also be beneficial due to the fact that political ideologies of left and right may endorse different qualities in different cultures. For instance, the conception of political left in Turkey is unlike the conception of left in USA or any Western European Countries. The left ideology in Turkey includes more conservative motives as compared to American left ideology. Therefore, such longitudinal and cross-cultural studies would be beneficial to reveal the variations in the meaning attributed to commonly referred conceptions and how their influences may change in time.

Lastly, the theoretical approach that specifically mediation model has been based on, would have been enriched by the theories of other disciplines like sociology and political science. As the authors of the study are mainly psychology scholars, they are more apt to introduce psychological theories. Therefore, the future studies should have a more multidisciplinary focus to enlighten different aspects of the voting behavior in Turkey.

Despite all empirical and theoretical limitations, the current study contributes to the available literature by extending previous work to a relatively under examined culture, and has provided partial support for the relationships between social-psychological predictors and intention of voting for certain parties in Turkey.

\section{References}

Ajzen, I. (1985). From intentions to actions: A theory of planned behavior. In Action control (pp. 11-39). Springer Berlin Heidelberg. doi:10.1007/978-3-642-69746-3_2

Ajzen, I. (1991). The theory of planned behavior. Organizational Behavior and Human Decision Processes, 50(2), 179-211. doi:10.1016/0749-5978(91)90020-T

Ajzen, I. (2012). Martin Fishbein's legacy: The reasoned action approach. The Annals of the American Academy of Political and Social Science, 640(1), 11-27. doi:10.1177/0002716211423363

Akbaş, G. (2010). Social identity and intergroup relations: The case of Alevis and Sunnis in Amasya. (Unpublished master's thesis). METU, Ankara, Turkey.

Akgün, B. (2002). Twins or enemies: Comparing nationalist and Islamist traditions in Turkish politics. Middle East Review of International Affairs, 6, 1, 17-35.

Alozie, N. O., Simon, J., \& Merrill, B. D. (2003). Gender and political orientation in childhood. The Social Science Journal, 40(1), 1-18.

Altemeyer, B. (1998). The other "authoritarian personality.” In M. P. Zanna (Ed.), Advances in Experimental Social Psychology, 30, (pp. 47-92). New York: Academic Press. 
Arin, K. Y. (2013). The AKP's foreign policy, Turkey's reorientation from the west to the east? Berlin: Wissenschaftlicher Verlag.

Arneil, B. (2006). Diverse communities: The problem with social capital. Cambridge: Cambridge University Press.

Barnea, M., \& Schwartz, S. H. (1998). Values and voting. Political Psychology, 19, 17-40. doi:10.1111/0162895X.00090

Başlevent, Kirmanoğlu, \& Şenatalar (2009). Party preferences and economic voting in Turkey (Now that the crisis is over). Party Politics, 15(3), 377-391. doi:10.1177/1354068808097896

Bianco, W. T. (1994). Trust: Representatives and constituents. Ann Arbor: University of Michigan Press. doi: $10.2307 / 2083009$

Caprara, G. V., Barbaranelli, C., \& Zimbardo, P. G. (2002). When parsimony subdues distinctiveness: Simplified public perception of politicians' personality. Political Psychology, 23(1), 77-96. doi:10.1111/0162-895X.00271

Caprara, G. V., Schwartz, S., Capanna, C., Vecchione, M., \& Barbaranelli, C. (2006). Personality and politics: Values, traits, and political choice. Political Psychology, 27, 1-28. doi:10.1111/j.1467-9221.2006. 00447.x

Caprara, G. V., Vecchione, M., Schwartz, S. H., Schoen, H., Bain, P. G., Silvester, J., Caprara, M. G. (2017). Basic values, ideological self-placement, and voting: A cross-cultural study. Cross-Cultural Research, 51(4), 388-411. doi:10.1177/1069397117712194

Çarkoglu, A. (2007). The nature of left-right ideological self-placement in the Turkish context. Turkish Studies, 8 (2), 253-271. doi:10.1080/14683840701312245

Çarkoğlu, (2008). Ideology or economic pragmatism? Profiling Turkish voters in 2007. Turkish Studies, 9(2), 317-344. doi:10.1080/14683840802012074

Çarkoğlu, A., \& Hinich, M. J. (2006). A spatial analysis of Turkish party preferences. Electoral Studies, 25(2), 369-392. doi:10.1016/j.electstud.2005.06.010

Chanley, V. A., Rudolph, T. J., \& Rahn, W. M. (2000). The origins and consequences of public trust in government: A time series analysis. Public Opinion Quarterly, 64(3), 239-256.

Citrin, J. (1974). Comment: The political relevance of trust in government. The American Political Science Review, 68(3), 973-988. doi:10.2307/1959141

Çoymak, A. (2009). Associations of religious identification, secular identification, perceived discrimination, and political trust with ethnic and societal (national) identification. (Unpublished Doctoral Dissertation). Ankara: Middle East Technical University.

Devos, T., Spini, D., \& Schwartz, S. H. (2002). Conflicts among human values and trust in institutions. British Journal of Social Psychology, 41, 481-494. doi:10.1348/014466602321149849

Dirilen-Gümüş, Ö. (2009). Relationship between values, personality culture and political ideology: A comparison of American and Turkish university students. (Unpublished Doctoral Dissertation). Ankara: University of Ankara.

Dirilen-Gümüş, Ö. (2010). The effect of religiosity on political ideology via value types and personality traits: A comparison between Turkey and USA. Procedia - Social and Behavioral Sciences, 5, 12-17. doi:10.1016/j.sbspro.2010.07.042

Dirilen-Gümüş, Ö. (2011). Differences in system justification with respect to gender, political conservatism, socio-economic status and religious fundamentalism. Procedia-Social and Behavioral Sciences, 30, 2607- 2611. doi:10.1016/j.sbspro.2011.10.510

Dirilen-Gümüş, Ö., Büyükşahin-Sunal, A. (2012). Gender-based differences in Turkish undergraduates’ values. Sex Roles, 67, 9, 559-570. doi:10.1007/s11199-012-0197-4

Dixon, J. C., \& Ergin, M. (2010). Explaining Anti-Kurdish beliefs in Turkey: Group competition, identity, and globalization. Social Science Quarterly, 91(5), 1329-1348. doi:10.1111/j.1540-6237.2010.00734.x

Doğan, M. (2005). Erosion of confidence in thirty European democracies. Comparative Sociology, 4, 11-54. doi:10.1163/1569133054621932

Duckitt, J. (2001). A dual-process cognitive-motivational theory of ideology and prejudice. In M. P. Zanna (Ed.), Advances in Experimental Social Psychology, 33, (pp. 41-113). San Diego: Academic Press. doi:10.1016/S0065-2601(01)80004-6

Emler, N., Renwick, S., \& Malone, B. (1983). The relationship between moral reasoning and political orientation. Journal of Personality and Social Psychology, 45(5), 1073-1080. doi:10.1037/00223514.45.5.1073 
Ercins, G. (2007). Türkiye'de sosyo-ekonomik faktörlere bağlı olarak değişen seçmen davranış1 [The voter behavior in Turkey changing according to socio-economic variables]. Cumhuriyet Üniversitesi İktisadi ve İdari Bilimler Dergisi, 9(2), 25-40.

Erder, N. (2002). Türkiye'de siyasi partilerin yandaş/seçmen profili:1994-2002. TÜSES Yayınları.

Erisen, C. (2016). An assessment on the behavioral foundations of electoral decisions in the 2015 Turkish general elections. Turkish Studies, 17(1), 47-57. doi:10.1080/14683849.2015.1136085.

Ersoy, E., \& Uysal, R. (2018). Opinions of School Psychological Counselors on Giftedness and Gifted Students' Education. American Journal of Qualitative Research, 2(2), 120-142.

EU plans to cut financial assistance to Turkey (6 May 2018). Ahval. Retrieved from https://ahvalnews.com/euturkey/eu-plans-cut-financial-assistance-turkey

Fishbein, M., \& Ajzen, I. (1975). Belief, attitude, intention, and behavior: An introduction to theory and research. Reading, MA: Addison-Wesley.

Fulton, D.C., Manfredo, M.J., \& Lipscomb, J. (1996). Wildlife value orientations: A conceptual and measurement approach. Human Dimensions Wildlife, 1(2), 22-47. doi:10.1080/10871209609359060

Grimmelikhuijsen, S., \& Knies, E. (2017). Validating a scale for citizen trust in government organizations. International Review of Administrative Sciences, 83(3), 583-601. doi:10.1177/0020852315585950

Hennessy, M., Carpini, M. X., Blank, M. B., Winneg, K., \& Jamieson, K. H. (2015). Using psychological theory to predict voting intentions. Journal of Community Psychology, 43(4), 466-483. doi:10.1002/jcop. 21697

Hetherington, M.J. (1998). The political relevance of political trust. American Political Science Review, 92(4), 791-808. doi:10.2307/2586304

Hetherington, M. J., (2005). Why trust matters: Declining political trust and the demise of American liberalism. Princeton: Princeton University Press.

Ho, A. K., Sidanius, J., Pratto, F., Levin, S., Thomsen, L., Kteily, N. S., \& Sheehy-Skeffington, J. (2012). Social dominance orientation: Revisiting the structure and function of a variable predicting social and political attitudes. Personality and Social Psychology Bulletin, 38(5), 583-606. doi: $10.1177 / 0146167211432765$

Hooghe, M., Marien, S., \& Pauwels, T. (2011). Where do distrusting voters turn if there is no viable exit or voice option? The impact of political trust on electoral behaviour in the Belgian regional elections of June 2009 . Government and Opposition 46 (2), 245-273. doi:10.1111/j.1477-7053.2010.01338.x

İnan, S. (2007). Demokrat Parti Dönemi (1950-1960). Yakın Dönem Türk Politik Tarihi. Ankara: Anı Yayıncılık, 117-145.

Janoff-Bulman, R., Sheikh, S., \& Baldacci, K. G. (2008). Mapping moral motives: Approach, avoidance, and political orientation. Journal of Experimental Social Psychology, 44(4), 1091-1099. doi:10.1016/j.jesp.2007.11.003

Jost, J. T., \& Banaji, M. R. (1994). The role of stereotyping in system-justification and the production of false consciousness. British Journal of Social Psychology, 33(1), 1-27. doi:10.1111/j.20448309.1994.tb01008.x

Jost, J. T., Banaji, M. R., \& Nosek, B. A. (2004). A decade of system justification theory: Accumulated evidence of conscious and unconscious bolstering of the status quo. Political Psychology, 25(6), 881-919. doi:10.1111/j.1467-9221.2004.00402.x

Jost, J. T., Burgess, D., \& Mosso, C. O. (2001). Conflicts of legitimation among self, group, and system: The integrative potential of status justification theory. In J. T. Jost, \& B. Major (Eds.), Psychology of Legitimacy (pp. 363-388). Cambridge: Cambridge University Press.

Jost, J. T., Glaser, J., Kruglanski, A. W., \& Sulloway, F. (2003). Political conservatism as motivated social cognition. Psychological Bulletin, 129(3), 339- 375. doi:10.1037/0033-2909.129.3.339

Jost, J. T., \& Hunyady, O. (2002). The psychology of system justification and the palliative function of ideology. European Review of Social Psychology, 13(1), 111-153. doi:10.1080/10463280240000046

Jost, J. T., Nosek, B. A., \& Gosling, S. D. (2008). Ideology: Its resurgence in social, personality, and political psychology. Perspectives on Psychological Science, 3(2), 126-136. doi:10.1111/j.17456916.2008.00070.x

Kalaycığlu, E. (2007). Politics of Conservatism in Turkey. Turkish Studies, 8, 233-252. doi:10.1080/14683840701312211

Kandler, C., Bleidorn, W., \& Riemann, R. (2012). Left, or right? Sources of political orientation: The roles of genetic factors, cultural transmission, assortative mating, and personality. Journal of Personality and Social Psychology, 102(3), 633. doi:10.1037/a0025560 
Karakus, M. (2018). The moderating effect of gender on the relationships between age, ethical leadership, and organizational commitment. Journal of Ethnic and Cultural Studies, 5(1), 74-84.

Karatas, K. \& Oral, B. (2015). Teachers' perceptions on culturally responsiveness in education. Journal of Ethnic and Cultural Studies, 2(2), 47-57.

Karpat, K. (1962). Recent political developments in Turkey and their social background. International Affairs (Royal Institute of International Affairs 1944-), 38(3), 304-323. doi:10.2307/2609442

Kay, A. C., Gaucher, D., Napier, J. L., Callan, M. J., \& Laurin, K. (2008). God and the government: Testing a compensatory control mechanism for the support of external systems. Journal of Personality and Social Psychology, 95(1), 18-35. doi:10.1037/0022-3514.95.1.18

Kay, A. C., \& Jost, J. T. (2003). Complementary justice: Effects of "poor but happy" and "poor but honest" stereotype exemplars on system justification and implicit activation of the justice motive. Journal of Personality and Social Psychology, 85(5), 823-837. doi:10.1037/0022-3514.85.5.823

Kayaalp, A. (2016). The impact of "temporal personality" on individuals' organizational citizenship behaviors. Journal of Management and Information Science, 4(2), 79-86.

Kayaalp, A. (2018). Transformational leadership, organizational climate and individual creativity from a military culture perspective. Electronic International Journal of Education, Arts, and Science, 4(9), 91-110.

Kayaoglu (2017). Determinant of trust in Turkey. European Societies, 19, $492-516$. doi:10.1080/14616696.2016.1228992

Kemahlığlu,Ö. (2015). Winds of change? The June 2015 parliamentary election in Turkey. South European Society and Politics, 20, 4, 445-464. doi:10.1080/13608746.2015.1115581

Kotluk, N. \& Kocakaya, S. (2018). Culturally relevant/responsive education: What do teachers think in Turkey? Journal of Ethnic and Cultural Studies, 5(2), 98-117.

Kumbaracıbaşı, A. C. (2014). Cumhuriyet Halk Partisi oylarının birikimli düzey analizi ve Türkiye'de merkez solun seçim coğrafyasının incelemesi. Amme Idaresi Dergisi, 47(4), 59-92.

Lee, E.-J., Oh, S. Y., Lee, J., \& Kim, H. S. (2018). Up close and personal on social media: When do politicians' personal disclosures enhance vote intention? Journalism \& Mass Communication Quarterly, 95(2), 381-403. doi:10.1177/1077699018754911

Mishler, W., \& Rose, R. (2001). What are the origins of political trust? Testing institutional and cultural theories in post-communist societies. Comparative Political Studies, 34(1), 30-62.

New clashes likely between Turkey, Europe (23 June 2017). Al-Monitor. Retrieved from https://www.almonitor.com/pulse/originals/2017/06/turkey-european-union-relations-possible-collision.html

Newton, K. (2008). Social and political trust. In R. Dalton \& H. Klingemann (Eds.), Oxford Handbook of Political Behavior (pp. 342-361). Oxford: Oxford University Press. doi:10.1093/oxfordhb/9780199270125.001.0001

Oniş (2013). Sharing Power: Turkey's Democratization Challenge in the Age of the AKP Hegemony. Insight Turkey, 15(2), 103-122.

Overbeck, J., Jost, J. T., Mosso, C., \& Flizik, A. (2004). Resistant vs. acquiescent responses to group inferiority as a function of social dominance orientation in the USA and Italy. Group Processes and Intergroup Relations, 7(1), 35- 54. doi:10.1177/1368430204039972

Owuamalam, C. K., Rubin, M., \& Spears, R. (2018). Addressing evidential and theoretical inconsistencies in system-justification theory with a social identity model of system attitudes. Current Directions in Psychological Science, 27(2), 91-96. doi:10.1177/0963721417737136

Özbudun, E. (2006). Changes and continuities in the Turkish party system. Journal of Representative Democracy, 42(2), 129-137. doi:10.1080/00344890600736366

Pratto, F., Çidam, A., Stewart, A. L., Zeineddine, F. B., Aranda, M., Aiello, A., ... \& Eicher, V. (2013). Social dominance in context and in individuals: Contextual moderation of robust effects of social dominance orientation in 15 languages and 20 countries. Social Psychological and Personality Science, 4(5), 587599. doi:10.1177/1948550612473663

Pratto, F., Sidanius, J., Stallworth, L. M., \& Malle, B. F. (1994). Social dominance orientation: A personality variable predicting social and political attitudes. Journal of Personality and Social Psychology, 67(4), 741-763.

Putnam, R. D. (1995). Tuning in, tuning out: The strange disappearance of social capital in America. Political Science \& Politics, 28(4), 664-683. doi:10.2307/420517

Putnam, R. D. (2000). Bowling alone: The collapse and revival of American community. New York, NY: Simon and Schuster. doi:10.15365/joce.0602122013 
Rooduijn, M., Burgoon, B., van Elsas, E. J., \& van de, H. G. (2017). Radical distinction: Support for radical left and radical right parties in Europe. European Union Politics, 18(4), 536-559. doi: $10.1177 / 1465116517718091$

Schwartz, S. H. (1992). Universals in the content and structure of values: Theory and empirical tests in 20 countries. In M. Zanna (Ed.), Advances in Experimental Social Psychology 25 (pp. 1-65). New York, NY: Academic Press. doi:10.1016/S0065-2601(08)60281-6

Schwartz, S. H. (2006). Value orientations: Measurement, antecedents and consequences across nations. In R. Jowell, C. Roberts, R. Fitsgerald, \& G. Eva (Eds.) Measuring Attitudes Cross-Nationally: Lessons from the European Social Survey (pp. 161-193). London: Sage. doi:10.4135/9781849209458.n9

Schwartz, S. H., \& Bilsky, W. (1990). Toward a theory of the universal content and structure of values: Extensions and cross-cultural replications. Journal of Personality and Social Psychology, 58(5), 878891. doi: $10.1037 / 0022-3514.58 .5 .878$

Schwartz, S. H., Cieciuch, J., Vecchione, M., Davidov, E., Fischer, R., Beierlein, C., ... \& Dirilen-Gümüş, O. (2012). Refining the theory of basic individual values. Journal of Personality and Social Psychology, 103(4), 663-688. doi:10.1037/a0029393

Shrout, P. E. \& Bolger, N. (2002). Mediation in experimental and non-experimental studies: New procedures and recommendations. Psychological Methods, 7(4), 422-445. doi:10.1037/1082-989X.7.4.422

Sidanius, J., Kteily, N., Sheehy-Skeffington, J., Ho, A., Sibley, C., \& Duriez, B. (2013). You're inferior and not worth our concern: The interface between empathy and social dominance orientation. Journal of Personality, 81(3), 313-323. doi:10.1111/jopy.12008

Sidanius, J., Levin, S., Liu, J., \& Pratto, F. (2000). Social dominance orientation, anti-egalitarianism, and the political psychology of gender: An extension and cross-cultural replication. European Journal of Social Psychology, 30(1), 41-67. doi:10.1002/(SICI)1099-0992(200001/02)30

Sidanius, J., \& Pratto, F. (1999). Social dominance: An intergroup theory of social hierarchy and oppression. New York: Cambridge University Press. doi:10.1017/CBO9781139175043

Sonmez, B. (2014). Politik güven: Dindarlık, yetkecilik, sistemi meşrulaştırma ve değerler açısından bir inceleme. (Unpublished Master's Thesis). Ankara: Ankara University.

Tarman, B. (2010) Global Perspectives and Challenges on Teacher Education in Turkey, International Journal of Arts \& Sciences (IJAS), 3(17): 78-96, United States.

Thorisdottir, H., Jost, J. T., Liviatan, I., \& Shrout, P. E. (2007). Psychological needs and values underlying leftright political orientation: Cross-national evidence from Eastern and Western Europe. Public Opinion Quarterly, 71(2), 175-203. doi:10.1093/poq/nfm008

TÜİK (2012). Milletvekili Genel Seçimleri 1923 - 2011.

Vaske, J.J. \& Donnelly, M.P. (1999). A Value-Attitude-Behavior Model Predicting Wildland Preservation Voting Intentions. Society \& Natural Resources, 12, 523537. doi:10.1080/089419299279425

Vecchione, M., Schoen, H., Castro, J. G., Cieciuch, J., Pavlopoulos, V., \& Caprara, G. V. (2011). Personality correlates of party preference: The Big Five in five big European countries. Personality and Individual Differences, 51(6), 737-742.

Verba, S., Burns, N., \& Schlozman, K. L. (1997). Knowing and caring about politics: Gender and political engagement. The Journal of Politics, 59(4), 1051-1072.

Yilmaz, H. (2008). Conservatism in Turkey. Turkish Policy Quarterly, 7(1), 57-63. doi:10.1111/j.15406261.1994.tb04418.x

Yıldırım, N. (2010). Sivil Toplum Kuruluşu Gönüllülerinin Adil Dünya İnançları, Sosyal Baskınlık Yönelimleri ve Sistemi Meşru Algılama Düzeyleri. (Unpublished dissertation). Mersin.

Yigit, M. (2018). Does higher education change value perceptions?. Journal of Culture and Values in Education, 1(1), 1-8. Retrieved from http://cultureandvalues.org/index.php/JCV/article/view/5

Zurcher, E. J. (2004). Turkey:A modern history. New York: I.B. Tauris. 